\title{
Distribution and Cellular Localization of mRNA Coding for 5-HT Receptor in the Rat Brain: Correlation with Receptor Binding
}

\author{
Maria Pompeiano, ${ }^{\mathrm{a}}$ José M. Palacios, ${ }^{\mathrm{b}}$ and Guadalupe Mengod ${ }^{\mathrm{b}}$ \\ Sandoz Pharma Limited, CH-4002 Basel, Switzerland
}

In order to localize the cells expressing 5-HT ${ }_{1 \mathrm{~A}}$ receptors in the rat brain, we used in situ hybridization histochemistry to visualize the distribution of the mRNA coding for 5-HT ${ }_{1 \mathrm{~A}}$ receptors. Oligonucleotides derived from different parts of the coding region of the rat 5-HT ${ }_{1 \mathrm{~A}}$ receptor gene were used as hybridization probes. 5-HT ${ }_{1 \mathrm{~A}}$ binding sites were visualized on consecutive sections by receptor autoradiography using ${ }^{3} \mathrm{H}-8$-hydroxy-2-(di-n-propylamino)tetralin as ligand.

The highest levels of hybridization were observed in the dorsal raphe nucleus, septum, hippocampus, entorhinal cortex, and interpeduncular nucleus. Positive hybridization signals were also present in other areas, such as the olfactory bulb; cerebral cortex; some thalamic and hypothalamic nuclei; several nuclei of the brainstem, including all the remaining raphe nuclei, nucleus of the solitary tract, and nucleus of the spinal tract of the trigeminus; and the dorsal horn of the spinal cord.

The distribution and abundance of 5-HT ${ }_{1 \mathrm{~A}}$ receptor mRNA in different rat brain areas generally correlate with those of the binding sites, suggesting that $5-\mathrm{HT}_{1 \mathrm{~A}}$ receptors are predominantly somatodendritic receptors.

Several different types of 5-HT receptors have been pharmacologically defined (Peroutka, 1990). The recent molecular cloning of the genes or the cDNAs for four of these receptors, 5- $\mathrm{HT}_{1 \mathrm{~A}}$, 5-HT ${ }_{\mathrm{IC}}, 5-\mathrm{HT}_{1 \mathrm{D}}$, and 5- $\mathrm{HT}_{2}$ (see Hartig, 1989, for a review; Branchek et al., 1991), has suggested that they all belong to the monomeric G-protein-coupled receptor family (Dohlman et al., 1987). The distribution of $5-\mathrm{HT}_{1 \mathrm{~A}}$ receptors has been examined in the rat brain by means of receptor autoradiographic technique (Marcinkiewicz et al., 1984; Pazos and Palacios, 1985) using a selective tritium-labeled ligand, 8-hydroxy-2-(di- $n$-propylamino)tetralin (8-OH-DPAT) (Arvidsson et al., 1981; Gozlan et al., 1983). Recently, 5-HT ${ }_{1 \mathrm{~A}}$ receptors have been also visualized by immunoautoradiography (El Mestikawy et al., 1990), using an antibody against a synthetic peptide derived from the predicted sequence of the rat $5-\mathrm{HT}_{1 \mathrm{~A}}$ receptor.

\footnotetext{
Received June 10, 1991; revised Sept. 3, 1991; accepted Sept. 10, 1991.

M.P. was supported by a fellowship from the CNR, Rome. We thank Prof. Ottavio Pompeiano and Dr. Lazaros Triarhou for critically reading the manuscript.

Correspondence should be addressed to Dr. G. Mengod, Departamento de Neuroquímica, CID-CSIC Jordi Girona 18-26, Barcelona E-08034, Spain.

a Present address: Instituto di Chimica Biologica, Universita di Pisa, Scuola Medica, via Roma n.55, I-56100 Pisa.

b Present address: Departamento de Neuroquimica, CID-CSIC Jordi Girona 18-26, Barcelona E-08034, Spain.

Copyright (c) 1992 Society for Neuroscience $0270-6474 / 92 / 120440-14 \$ 05.00 / 0$
}

The light microscopic autoradiographic techniques used until now did not allow the unequivocal establishment of the cellular localization of receptors, which could only be inferred indirectly (Palacios and Dietl, 1988). A presynaptic localization of 5-HT receptors on the cell body and dendrites of serotoninergic cells, which would be responsible for the autoinhibition of 5-HT cells in the dorsal raphe (Wang and Aghajanian, 1977), is supported by biochemical (Hjorth et al., 1982), lesion (Weissman-Nanopoulos et al., 1985; Vergé et al., 1986), and electrophysiological (Aghajanian et al., 1988) experiments. The cellular localization of $5-\mathrm{HT}_{1 \mathrm{~A}}$ receptors in the projection areas of the raphe nuclei is less clear (Palacios and Dietl, 1988). However, in the hippocampus, lesion experiments suggested a localization of the receptors to neurons intrinsic to this region (Hall et al., 1985), and electrophysiological experiments pointed in particular to the hippocampal pyramidal cells (Colino and Halliwell, 1987). In order to study the distribution of the neuronal populations expressing $5-\mathrm{HT}_{1 \mathrm{~A}}$ receptors in the rat brain, we used in situ hybridization histochemistry to detect the distribution of the mRNA coding for 5- $\mathrm{HT}_{1 \mathrm{~A}}$ receptors. The advantage of this technique over receptor autoradiography is the ability to visualize the cell bodies of neurons expressing $5-\mathrm{HT}_{1 \mathrm{~A}}$ receptors, as opposed to mapping the distribution of the binding site itself.

\section{Materials and Methods}

Animals. Wistar rats (male, $200-300 \mathrm{gm}$ ) were killed by decapitation, and the brains were quickly removed, frozen, and stored at $-70^{\circ} \mathrm{C}$ until sectioned. Sections $(20 \mu \mathrm{m}$ thick) were cut with a microtome cryostat (Leitz 1720), thaw-mounted onto gelatin-coated slides, and kept at $-20^{\circ} \mathrm{C}$ until use.

Hybridization probes and Northern analysis. Three different oligonucleotides were used complementary to the mRNA nuclcotides coding for the amino terminus (amino acids 1-16, oligo $N$ ), the third cytoplasmic loop (amino acids 255-270, oligo CL), and the carboxy terminus (amino acids $407-422$, oligo $\mathrm{C}$ ) of the rat $5-\mathrm{HT}_{1 \mathrm{~A}}$ receptor (Albert et al., 1990). The probes were synthesized on a 380B Applied Biosystems DNA synthesizer (Foster City Biosystems, Foster City, CA) and purified on a $20 \%$ polyacrylamide $/ 8 \mathrm{M}$ urea preparative sequencing gel. The oligonucleotides were labeled at their $3^{\prime}$ end with terminal deoxynucleotidyltransferase (Boehringer Mannheim) and $\alpha^{32}$ P-dATP $(3000 \mathrm{Ci} /$ mmol; DuPont New England Nuclear, Boston, MA) following the protocol described previously (Mengod et al., 1989).

PolyA $^{+}$RNA isolated from different dissected rat brain regions was blotted onto nylon membranes, and blots were then hybridized with the corresponding oligonucleotide as in Mengod et al. (1989).

In situ hybridization histochemistry. Frozen tissue scctions were fixed and then hybridized with the corresponding labeled oligonucleotide probe as described in Vilaró et al. (1991b) except that the hybridization buffer contained $40 \%$ formamide and in addition $10 \%$ dextran sulfate and that the washing temperature was $60^{\circ} \mathrm{C}$. The hybridized tissue sections were apposed to $\beta$ max films (Amersham) for 3 weeks at $-70^{\circ} \mathrm{C}$ with an intensifying screen. Duplicates of the hybridized sections were dipped into Kodak NTB-3 nuclear track emulsion diluted 1:1 with 0.6 
$M$ ammonium acetate. The emulsion was developed after 4 weeks in Kodak D19; tissues were then stained with cresyl violet, dehydrated, and mounted. Sections were examined using bright- and dark-field light microscopy (Leitz, Orthoplan photomicroscope).

Receptor autoradiography. 5-HT $\mathrm{HA}_{1 \mathrm{~A}}$ receptor binding sites were visualized in consecutive slides using ${ }^{3} \mathrm{H}-8$-OH-DPAT $(204 \mathrm{Ci} / \mathrm{mmol}$; DuPont New England Nuclear, Boston, MA) as a ligand and following the conditions already described (Marcinkiewicz et al., 1984; Pazos and Palacios, 1985).

\section{Results and Discussion}

Control experiments

The specificity of the hybridization signals was verified by a series of control experiments. When the three oligonucleotides were used as independent hybridization probes in consecutive tissuc sections, the same cellular pattern of hybridization was obtained (Fig. 1A-C). The concentrations of the probes resulting in the best signal-to-noise ratio were determined in saturation experiments (not shown). A probe concentration of about $1 \mathrm{~nm}$ in the hybridization buffer was found to be optimal. Cohybridization experiments were carried out, in which increasing concentrations of the same unlabeled probe were added to the hybridization buffer in consecutive sections; the hybridization signals were completely blocked, resulting in background levels, by competition of the ${ }^{32} \mathrm{P}$-labeled probe with a 20 -fold excess of the corresponding unlabeled oligonucleotide (Fig. $1 D, E$ ). In contrast, the hybridization signals were not blocked by an excess of the other two probes (Fig. $1 F$ ). Melting curve analysis showed that melting temperatures of the hybrids were in good agreement with the theoretically predicted values (Albretsen et al., 1988) (Fig. 1G-J). Northern blot analysis using the labeled oligonucleotide probes revealed a regional distribution of $5-\mathrm{HT}_{1 \mathrm{~A}}$ receptor mRNA in agreement with that observed in hybridized tissue sections (not shown).

The specificity of labeling of 5- $\mathrm{HT}_{1 \mathrm{~A}}$ sites by ${ }^{3} \mathrm{H}-8-\mathrm{OH}-\mathrm{DPAT}$ has been extensively documented (Vergé et al., 1986; Palacios and Dietl, 1988). ${ }^{3} \mathrm{H}-8-\mathrm{OH}-\mathrm{DPAT}$ binding in all brain regions examined was completely blocked with high affinity by 5-HTand $5-\mathrm{HT}_{1}$-selective agents such as ipsapirone, while $5-\mathrm{HT}_{1 \mathrm{~B}}$, $5-\mathrm{HT}_{1 \mathrm{C}}, 5-\mathrm{HT}_{2}$, or $5-\mathrm{HT}_{3}$ compounds such $\mathrm{SDZ}(-) 21009$, mesulergine, ketanserin, and ICS 205-930 presented lower or no affinity for the sites labeled by this ligand (Vergé et al., 1986; Palacios and Dietl, 1988; J. M. Palacios, unpublished observations). In the conditions used in this study, no binding of ${ }^{3} \mathrm{H}-$ 8-OH-DPAT to any of the 5-HT receptors described until now was found, in good agreement with previous extensive literature.

\section{Distribution of $5-\mathrm{HT}_{1 \mathrm{~A}}$ receptor mRNA and binding sites}

The distribution of hybridization signals obtained with oligo $\mathrm{C}$ as probe is shown in Figure $2 A-L$. The same pattern was obtained with the other two oligonucleotide probes. The distribution of $5-\mathrm{HT}_{1 \mathrm{~A}}$ receptors, as identified by ${ }^{3} \mathrm{H}-8-\mathrm{OH}-\mathrm{DPAT}$ binding in tissue slides consecutive to those used for hybridization experiments, is illustrated in Figure $2 A^{\prime}-L^{\prime}$. The results from both hybridization and binding experiments are summarized in Table 1. From the comparison between the distribution of mRNA and receptors, we had insight into the localization of 5-HT $1 \mathrm{~A}$ receptors on the neurons expressing them. In fact, while in situ hybridization identifies the cell body of neurons synthesizing the receptor, receptor autoradiography localizes binding sites to receptors, which may be localized on the cell body as well as on distal processes. The highest levels of both 5-HT ${ }_{1 \mathrm{~A}}$ mRNA and binding sites were seen in the dorsal raphe nucleus, septum, hippocampal formation, entophinal cortex, and interpeduncular nucleus.

\section{Raphe nuclei}

Very high levels of hybridization were found in the dorsal raphe (Figs. $2 G, H, 3 A$ ). Lower levels were seen in the other raphe nuclei such as the caudal linear, median raphe (Fig. $2 G, H$ ), raphe pontis (Fig. $3 B$ ), raphe magnus (Fig. 3C), raphe obscurus (Figs. $2 I ; 3 C, D$ ), and raphe pallidus (Figs. $2 I, 3 D$ ) nuclei. The dorsal raphe nucleus also presented a very high density of ${ }^{3} \mathrm{H}-8-\mathrm{OH}-$ DPAT binding sites (Fig. $2 G^{\prime}, H^{\prime}$ ), while the other raphe nuclei showed a lower density of sites (Fig. $2 G^{\prime}-I^{\prime}$ ). The raphe nuclei represent the principal source of serotoninergic innervation (Dahlström and Fuxe, 1964). The spatial distribution of the binding sites correspond well with that of the dendritic field of the 5-HT neurons, which are known to extend only a few dendrites located in the proximity of the cell body (Steinbush, 1984). The somatic and dendritic localization of $5-\mathrm{HT}_{1 \mathrm{~A}}$ receptors on 5-HT neurons is supported by several lines of evidence (see introductory remarks). Further support for this hypothesis has been obtained by selective lesion of 5-HT cells with intracerebroventricular administration of 5,7-dihydroxytryptamine (5,7DHT), which resulted in the loss of the hybridization signal and ${ }^{3} \mathrm{H}-8$-OH-DPAT binding (Pompeiano, Palacios, and Mengod, unpublished observations).

\section{Septum and hippocampal formation}

The septum showed very high levels of $5-\mathrm{HT}_{1 \mathrm{~A}}$ receptor mRNA in the medial nucleus (Figs. $2 C ; 4 A, D$ ) and nucleus of the vertical limb of the diagonal band of Broca (Figs. $2 C, 4 A$ ), high levels in the lateral nucleus (Figs. $2 C, 4 A, D$ ) and nucleus of the horizontal limb of the diagonal band of Broca, and low levels in the septofimbrial nucleus. 5-HT $\mathrm{IA}_{\mathrm{A}}$ sites, on the contrary, were present at very high and at high concentrations in the lateral nucleus (Figs. $2 C^{\prime} ; 4 B, E$ ) and vertical limb of the diagonal band (Figs. $2 C^{\prime}, 4 B$ ), respectively, while only low concentrations were seen in the medial nucleus (Figs. $2 C^{\prime} ; 4 B, E$ ), horizontal limb of the diagonal band of Broca, and septofimbrial nucleus. An explanation for the discrepancy seen in the medial septum is not yet available. It has been suggested that $5-\mathrm{HT}_{1 \mathrm{~A}}$ receptors were presynaptically located on the terminals of septohippocampal fibers (Quirion and Richard, 1987; Aghajanian et al., 1988). However, this was in contrast with the complete loss of $5-\mathrm{HT}_{1 \mathrm{~A}}$ receptors observed in the hippocampus after local injection of kainic acid (Hall et al., 1985; Palacios and Dietl, 1988; Palacios et al., 1990). In order to identify the neurochemical nature of the cells expressing 5-HT ${ }_{1 \mathrm{~A}}$ receptors in the medial septum (Leranth and Frotscher, 1989), we performed colocalization studies. Slides (10 $\mu \mathrm{m}$ thick) consecutive to those used for $5-\mathrm{HT}_{\mathrm{IA}}$ receptor mRNA identification were hybridized with probes for either glutamic acid decarboxylase or ChAT mRNA. Preliminary results indicate that $5-\mathrm{HT}_{1 \mathrm{~A}}$ receptors are expressed by both GABAergic and cholinergic cells.

The hippocampal formation presented one of the highest densities of both 5-HT $\mathrm{T}_{1 \mathrm{~A}}$ receptor mRNA and sites. Very strong hybridization signals were seen in the granule cell layer of the dentate gyrus (Figs. $2 E, F ; 5 A$ ) and the pyramidal cell layer of Ammon's horn, particularly in CA1 and CA4 (Figs. $2 E, F ; 5 A$ ) and in the most ventral levels of CA2 and CA3 (Fig. $2 F$ ), while in CA2 and CA3 at dorsal levels the signals were lower (Figs. $2 E, 5 A$ ). On the contrary, $5-\mathrm{HT}_{1 \mathrm{~A}}$ receptors were mainly localized in the molecular layer of the dentate gyrus, where they were 
A
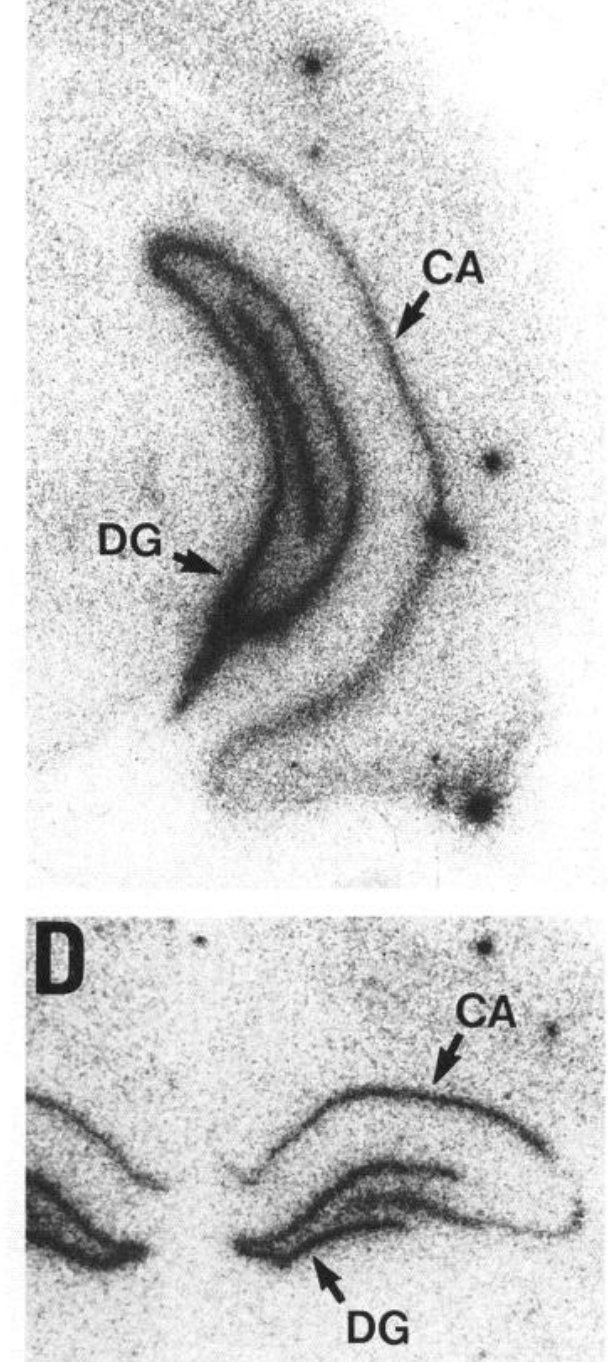

G


B

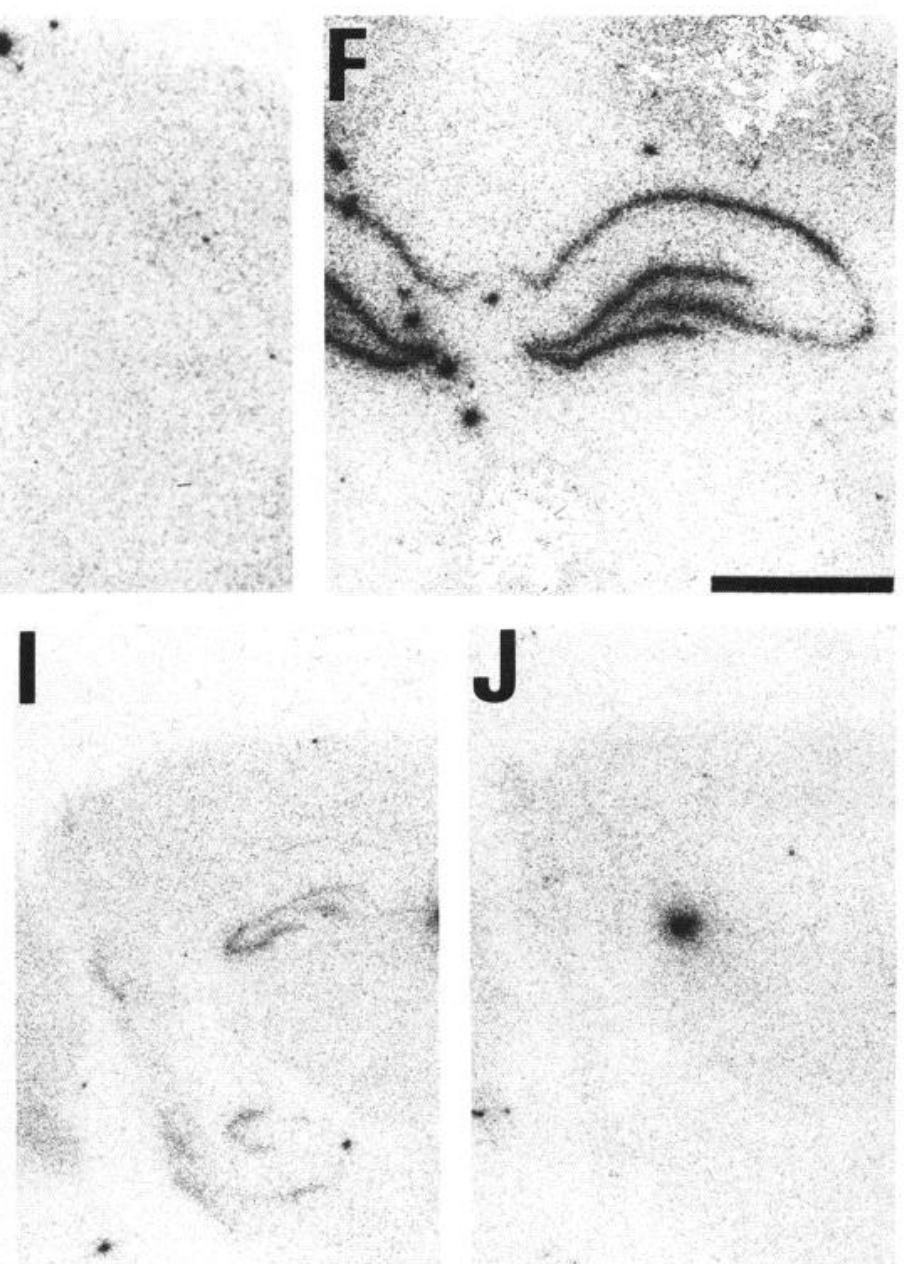
Table 1. Distribution of 5-HT, receptor mRNA and ligand binding in the rat brain

\begin{tabular}{|c|c|c|}
\hline Brain area & mRNA & Binding \\
\hline \multicolumn{3}{|l|}{ Raphe nuclei } \\
\hline Dorsal raphe nucleus & ++++ & ++++ \\
\hline Other raphe nuclei & +++ & +++ \\
\hline \multicolumn{3}{|l|}{ Septum } \\
\hline Medial septal nucleus & ++++ & ++ \\
\hline $\begin{array}{l}\text { Nucleus of the vertical limb of the } \\
\text { diagonal band of Broca }\end{array}$ & $++t$ & +++ \\
\hline $\begin{array}{l}\text { Nucleus of the horizontal limb of the } \\
\text { diagonal band of Broca }\end{array}$ & +++ & + \\
\hline Lateral septal nucleus & +++ & +++ \\
\hline \multicolumn{3}{|l|}{ Hippocampal formation } \\
\hline \multicolumn{3}{|l|}{ Dentate gyrus } \\
\hline Molecular layer & - & +++ \\
\hline Granule cell layer & ++++ & ++ \\
\hline \multicolumn{3}{|l|}{ CAl field } \\
\hline Stratum oriens & - & +++ \\
\hline Pyramidal cell layer & +++ & ++ \\
\hline Stratum radiatum & - & ++++ \\
\hline Stratum lacunosum moleculare & - & ++ \\
\hline Taenia tectae & +++ & +++ \\
\hline \multicolumn{3}{|l|}{ Olfactory system } \\
\hline \multicolumn{3}{|l|}{ Olfactory bulb } \\
\hline External plexiform layer & - & ++ \\
\hline Mitral cell layer & ++ & ++ \\
\hline Internal granular layer & ++ & + \\
\hline Anterior olfactory nucleus & ++ & ++ \\
\hline Endopiriform nucleus & ++ & ++ \\
\hline \multicolumn{3}{|l|}{ Cerebral cortex } \\
\hline Neocortex & ++ & ++ \\
\hline Anterior cingulate cortex & ++ & ++ \\
\hline Posterior cingulate cortex & + & + \\
\hline Retrosplenial cortex & ++ & ++ \\
\hline Primary olfactory cortex & ++ & ++ \\
\hline Entorhinal cortex & +++ & +++ \\
\hline \multicolumn{3}{|l|}{ Basal ganglia and related areas } \\
\hline Basal ganglia & - & - \\
\hline Fundus striati & + & + \\
\hline Claustrum & ++ & ++ \\
\hline Bed nucleus of the stria terminalis & ++ & ++ \\
\hline Subthalamic nucleus & + & + \\
\hline \multicolumn{3}{|l|}{ Amygdala } \\
\hline Nucleus of the lateral olfactory tract & ++ & ++ \\
\hline Anterior cortical nucleus & ++ & ++ \\
\hline Medial nucleus & ++ & ++ \\
\hline Amygdalohippocampal area & ++ & ++ \\
\hline
\end{tabular}

Table 1. Continued

Brain area mRNA Binding

Thalamus

Reticular thalamic nucleus

Intralaminar nuclei

Medial geniculate nucleus

Ventrolateral geniculate nucleus

Medial habenular nucleus

Hypothalamus

Medial preoptic area

Anterior hypothalamic area

Ventromedial nucleus

Dorsomedial nucleus

Posterior hypothalamic nucleus

Tuberal magnocellular nucleus

Submammillothalamic nucleus

Lateral mammillary nucleus

Brainstem and spinal cord

Anterior pretectal area

Interpeduncular nucleus

Superior colliculus

Inferior colliculus

Ventral nucleus of the

lateral lemniscus

Parabrachial nuclei

Dorsal tegmental nucleus

Superior vestibular nucleus

Prepositus hypoglossal nucleus

Nucleus of the solitary tract

Nucleus of the spinal tract

of the trigeminus

Dorsal horn of the spinal cord

$++\quad++$

$+\quad+$

$++\quad++$

$++\quad+$

$+++$

$+\quad+$

$+\quad+$

$++\quad++$

$+\quad+$

$+\quad+$

$+++++$

$++\quad+$

$++\quad++$

$+++\quad++++$

$+\quad++$

$++\quad++$

$+++\quad++$

$+\quad+$

$+++\quad+++$

$+\quad+$

$+++++$

$+++++$

$+t+t$

$+\quad+++$ $++\quad++$ more abundant in the internal than in the external limb (Fig. $5 B$ ), and in strata oriens and radiatum of Ammon's horn, particularly in CAl and CA4 (Figs. $2 E^{\prime \prime}, F^{\prime \prime} ; 5 B$ ) and the ventral portions of CA2 and CA3 (Fig. $2 F^{\prime}$ ). However, if we consider the dendritic organization of the pyramidal cells of the Ammon's horn and the granule cells of the dentate gyrus (Bayer, 1985), the different layer distribution of mRNA and receptors is easily accounted for by a preferential location of $5-\mathrm{HT}_{1 \mathrm{~A}}$ receptor on the dendrites of these two cell types. The taenia tectae showed high levels of both mRNA and receptors (Fig. $2 B, B^{\prime}$ ). Cells presenting positive hybridization signals were seen in the nucleus of the dorsal hippocampal commissure.

Figure 1. Control experiments for the specificity of the hybridization signals. In $A-C$, the same hybridization pattern was obtained in consecutive slides of rat hippocampus hybridized with the three different probes, oligos $\mathrm{N}, \mathrm{CL}$, and $\mathrm{C}$, respectively. In $D-F$, cohybridization experiments are shown. The signal obtained with the labeled oligo $\mathrm{C}(D)$ was completely blocked by competition with a 20 -fold excess of the corresponding unlabeled probe $(E)$ but not by an excess of the unlabeled oligo $\mathrm{N}(F)$. In $G-J$ are the signals obtained on consecutive slides hybridized with the oligo $C$ and washed at increasing temperatures: $60,70,80$, and $90^{\circ} \mathrm{C}$, respectively. A large decrease in the signal intensity was observed between $70^{\circ} \mathrm{C}$ and $80^{\circ} \mathrm{C}$. See Appendix for abbreviations used in figures. Scale bars, $2 \mathrm{~mm}$. 


\section{Olfactory system}

In the olfactory bulb, the mitral cell layer and internal granular layer showed hybridization signals of intermediate density (Fig. $2 A$ ). ${ }^{3} \mathrm{H}-8-\mathrm{OH}-\mathrm{DPAT}$ binding at this level (Fig. $2 A^{\prime}$ ) presented an intermediate density in the external layers, which included the glomerular and external plexiform layers, and a low density in correspondence to the internal granular layer. It is reasonable to conclude that $5-\mathrm{HT}_{1 \mathrm{~A}}$ receptors are mainly located on the dendrites of the mitral and the internal granular cells, since the glomerular layer contains branches of the primary apical dendrite of the mitral cells; the external plexiform layer, the secondary dendrites of these cells but also the large peripheral dendrites of the internal granular cells; and the internal granular layer, smaller dendrites of the internal granular cells (Switzer et al., 1985). 5-HT ${ }_{1 \mathrm{~A}}$ receptor mRNA and sites were both present at intermediate concentrations in the endopiriform nucleus (Figs. $\left.2 D, D^{\prime} ; 6 B\right)$ and the anterior olfactory nucleus, except in the external subnucleus, where they showed high concentrations.

\section{Cerebral cortex}

In the neocortex, the level of hybridization was intermediate (Fig. 2B-H). Labeled cells were observed scattered throughout the neocortex, but two bands were more clearly recognized in layer 5 (Fig. $6 \mathrm{~A}$ ) and layer 6 . The neocortex also presented an intermediate density of binding sites that was higher in the deep layers, where two stronger bands could be distinguished, than in the superficial ones (Fig. $2 B^{\prime}-H^{\prime}$ ). The presence of hybridization signals in layer 5 would point to an expression of $5-\mathrm{HT}_{1 \mathrm{~A}}$ receptors by pyramidal cells, as also suggested by electrophysiology experiments (Pierce and Peroutka, 1990). Our results also showed that cells intrinsic to layer 6 expressed $5-\mathrm{HT}_{1 \mathrm{~A}}$ sites. From these data, we suggest a localization of the receptors on the basal dendrites and cell bodies of the pyramidal cells of layer 5 and on neurons in layer 6 , which would account for the two stronger bands seen in ${ }^{3} \mathrm{H}-8-\mathrm{OH}-\mathrm{DPAT}$ binding in the internal layers of the cortex, as well as on the apical dendrites of the pyramidal cells, which would contribute to the binding present in the external layers.

The hybridization signals in the anterior cingulate cortex (Fig. $2 C$ ) and retrosplenial cortex (Fig. 2G) were stronger than in neocortex and present mainly over layers 2 and 5 . The hybridization was very low in the posterior cingulate cortex (Fig. $2 E, F$ ). ${ }^{3} \mathrm{H}-8-\mathrm{OH}-\mathrm{DPAT}$ binding was also higher in the anterior cingulate cortex (Fig. 2 $C^{\prime}$ ) and retrosplenial cortex (Fig. 2 $G^{\prime}$ ) than in the neocortex and was very low in the posterior cingulate cortex (Fig. $2 E^{\prime}, F^{\prime}$ ). The primary olfactory cortex showed intermediate levels of hybridization (Fig. $2 B, D$ ), with cells labeled in layers 2 and 3 (Fig. $6 B$ ). 5-HT ${ }_{1 A}$ receptors were distributed in two bands of different density (Fig. $2 D^{\prime}$ ), the internal presenting high levels, and the external, intermediate levels. Since the pyramidal neurons of layer 2 have several basal dendrites directed to the deep layer and a single apical dendrite directed to the superficial layer (Switzer et al., 1985), the results from binding and hybridization studies fit well with a location of
$5-\mathrm{HT}_{1 \mathrm{~A}}$ receptors on the dendrites of the pyramidal cells. In addition, receptors observed in the deep layer are at least in part expressed also by cells intrinsic to layer 3 . In the entorhinal cortex, a bilaminar pattern of the hybridization signal was present (Fig. 2G,H): a very strong band was seen in layer 2 (Fig. 6C) while a second wide band of lower intensity was present in layers 5 and 6 (Fig. $6 \mathrm{C}$ ). 5- $\mathrm{HT}_{\mathrm{IA}}$ receptors also showed at this level a very high concentration and were distributed in two bands in the external and internal layers separated by an intermediate layer including the lamina dissecans devoid of specific binding (Fig. $2 G^{\prime}, H^{\prime}$ ). These results suggest that $5-\mathrm{HT}_{1 \mathrm{~A}}$ receptors are present on the somata and dendrites of the large stellate cells of layer 2 and on the granule cells of layer $5 / 6$.

\section{Basal ganglia and related areas}

5-HT $\mathrm{T}_{1 \mathrm{~A}}$ receptor $\mathrm{mRNA}$ and sites were not detected in the basal ganglia and substantia nigra, whereas they were present at intermediate density in the claustrum (Fig. 2D,D) and bed nucleus of the stria terminalis and at low intensity in the subthalamic nucleus and fundus striati. They both showed intermediate levels in different nuclei of the amygdala, such as the nucleus of the lateral olfactory tract and anterior cortical nucleus (Fig. $2 D, D)$; medial and basomedial nucleus (Fig. $2 E$ ); and amygdalohippocampal area; and low levels in the central and basolateral nuclei. Cells presenting strong hybridization signals were found immediately dorsal to the horizontal limb of the diagonal band of Broca and scattered inside the internal capsule, areas belonging to the basal nucleus of Meynert.

\section{Thalamus and hypothalamus}

In the thalamus, 5-HT ${ }_{1 \mathrm{~A}}$ receptor $\mathrm{mRNA}$ and sites showed intermediate levels in the dorsal tip of the reticular nucleus (Fig. $2 D, D$ ), the medial part of the medial habenula (Fig. $5 A, B$ ), and the medial geniculate nucleus (Fig. $2 F, F^{\prime}$ ) and low or very low levels in the intralaminar nuclei, such as the centromedial (Fig. $2 E, E$ ) and centrolateral nuclei, and the magnocellular portion of the ventrolateral geniculate nucleus. In the hypothalamus, mRNA and receptors presented high concentrations in the tuberal magnocellular nucleus, intermediate concentrations in the ventromedial (Fig. $2 E, E$ ), submammillothalamic, and lateral mammillary nuclei, and low concentrations in the medial preoptic area, anterior hypothalamic area, dorsomedial nucleus (Fig. $2 E, E)$, and posterior hypothalamic nucleus.

\section{Brainstem and spinal cord}

Besides the raphe system, described above, very high levels of hybridization in the brainstem were observed in the interpeduncular complex (Fig. $2 F$ ), with the exception of its inner posterior subnucleus, and high levels were observed in the ventral nucleus of the lateral lemniscus (Fig. $2 G, H$ ); dorsal tegmental nucleus of Gudden (Fig. 3B); prepositus hypoglossal nucleus (Fig. 2I), particularly in its ventromedial part; and the nucleus of the solitary tract (Fig. $2 I, J$ ).

Strongly labeled cells and binding were seen in areas known to contain extra-raphe serotoninergic neurons: the region im-

Figure 2. Regional distribution of 5-HT $\mathrm{HA}_{1 \mathrm{~A}}$ receptor mRNA and binding sites in the rat brain. In $A-L$ are film autoradiograms from sections hybridized with the ${ }^{32} \mathrm{P}$-labeled oligo $\mathrm{C}$. In $A^{\prime}-L^{\prime}$ are autoradiograms obtained from consecutive sections incubated with ${ }^{3} \mathrm{H}-8-\mathrm{OH}-\mathrm{DPAT}$. The asterisk in $I^{\prime}$ indicates the labeled area immediately dorsal to the inferior olive. Coronal brain sections are presented in a rostrocaudal progression. Scale bars, $2 \mathrm{~mm}$. 
A

$A^{\prime}$

v
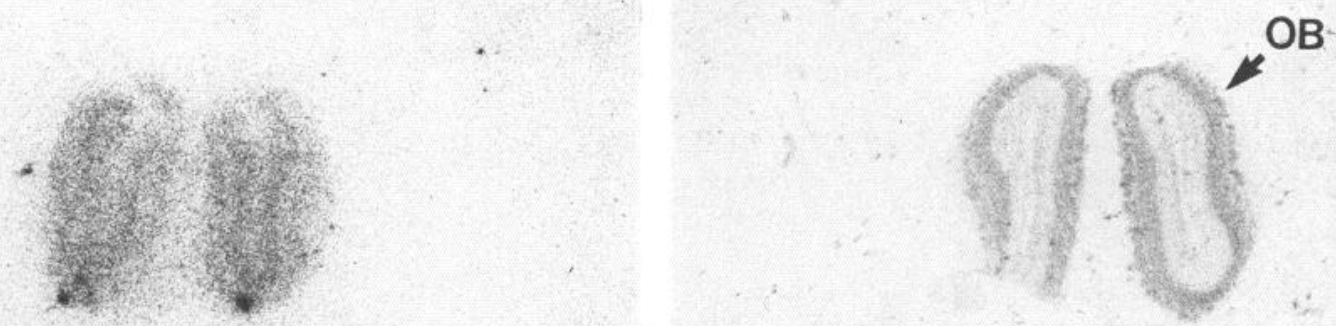

B

$B^{\prime}$
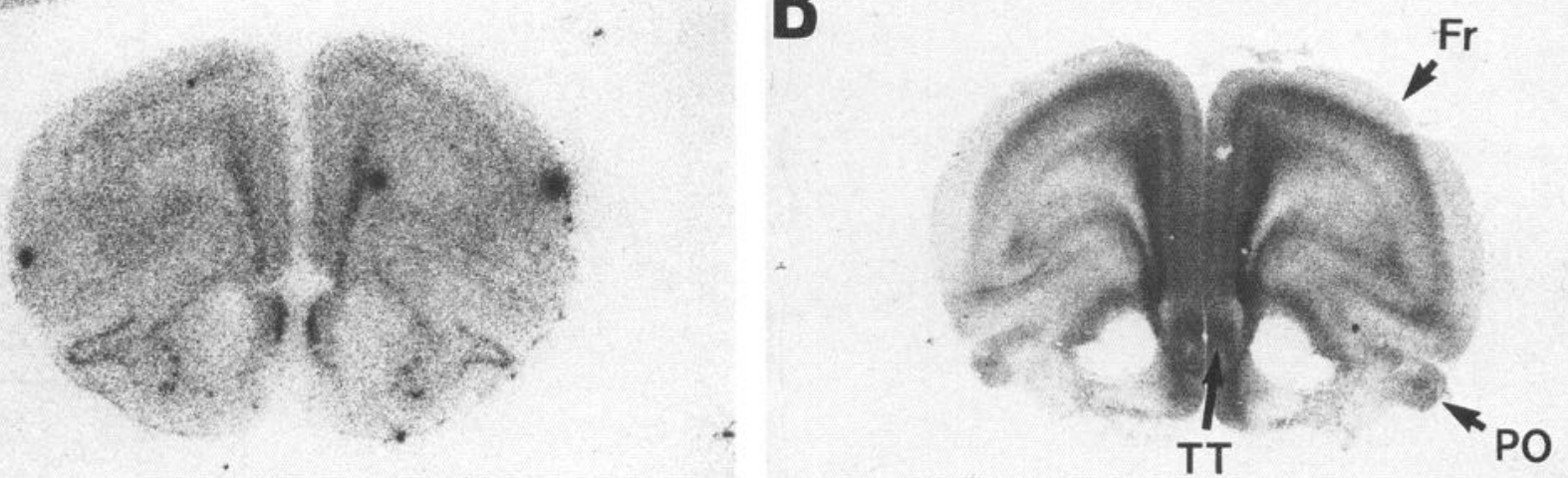

C

C'



D

D'
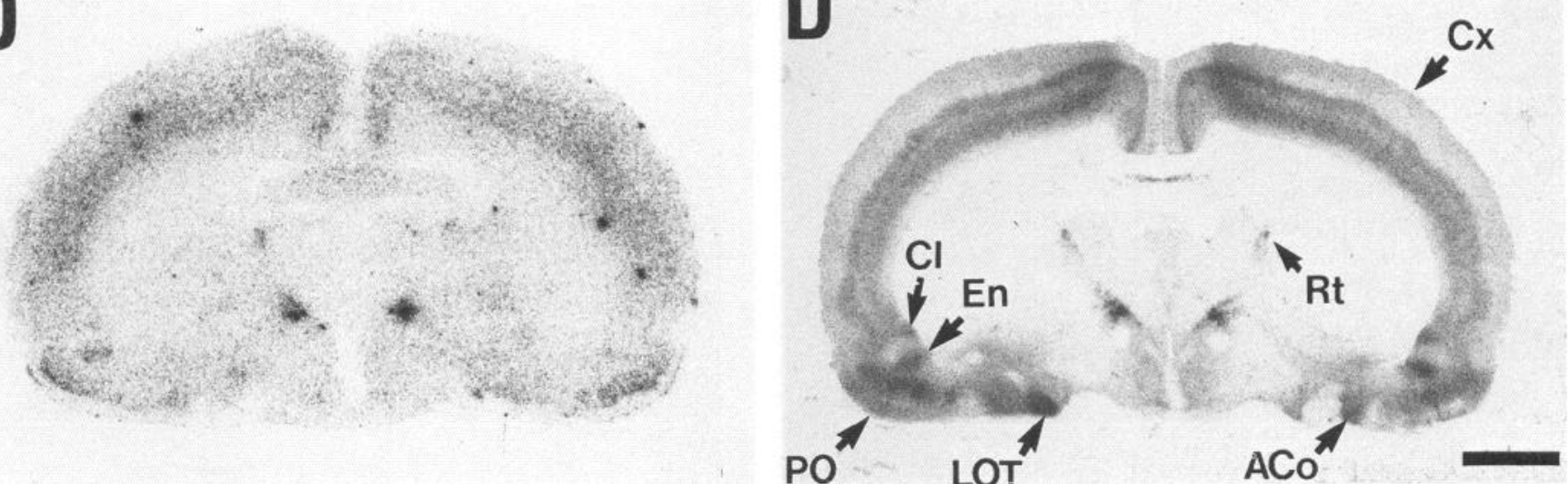
E



F

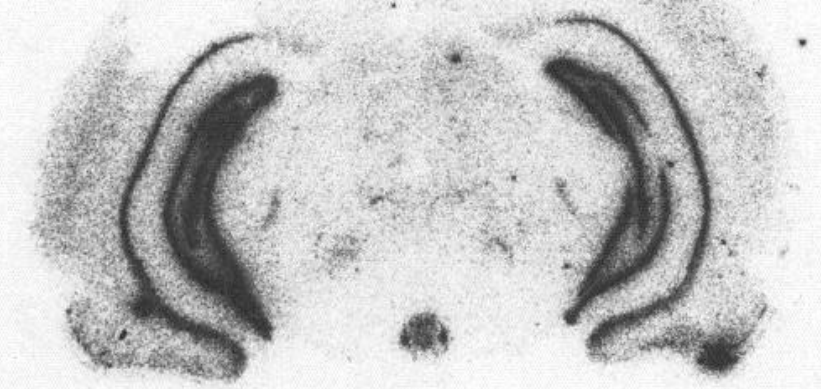

G

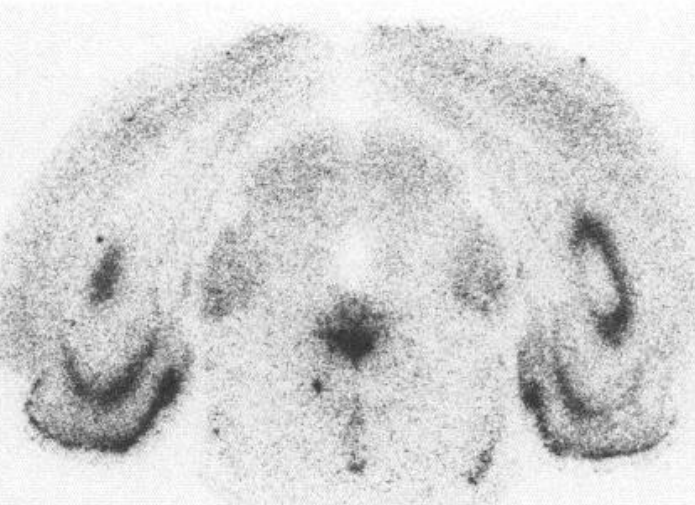

H

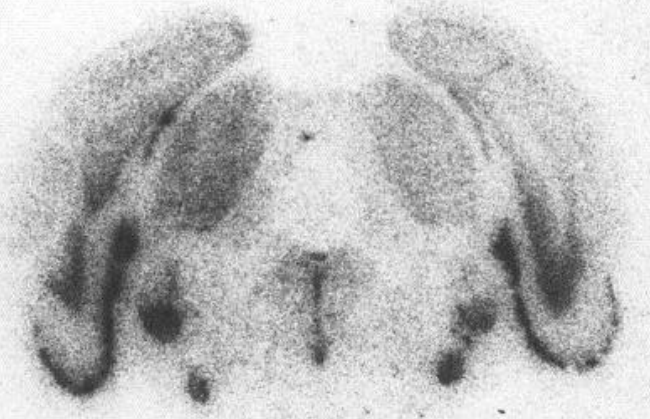

$E^{\prime}$

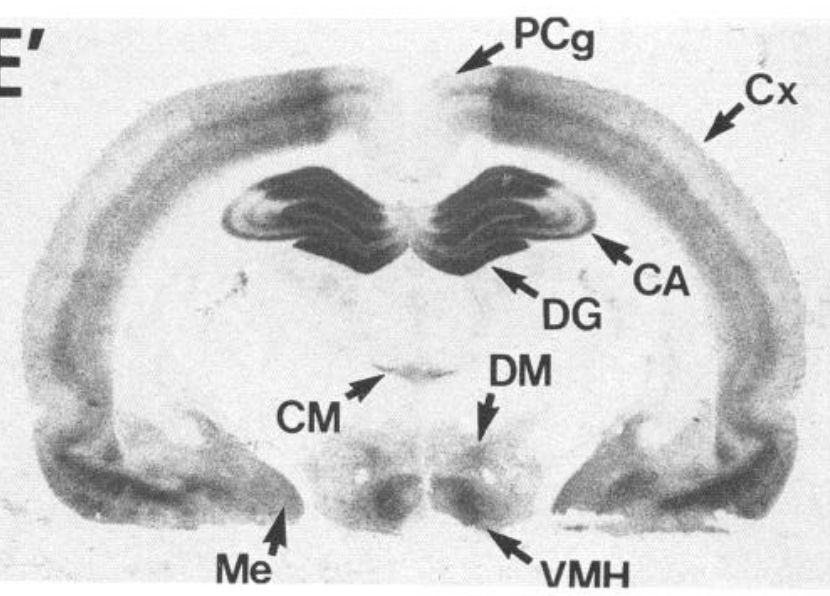

$F^{\prime}$
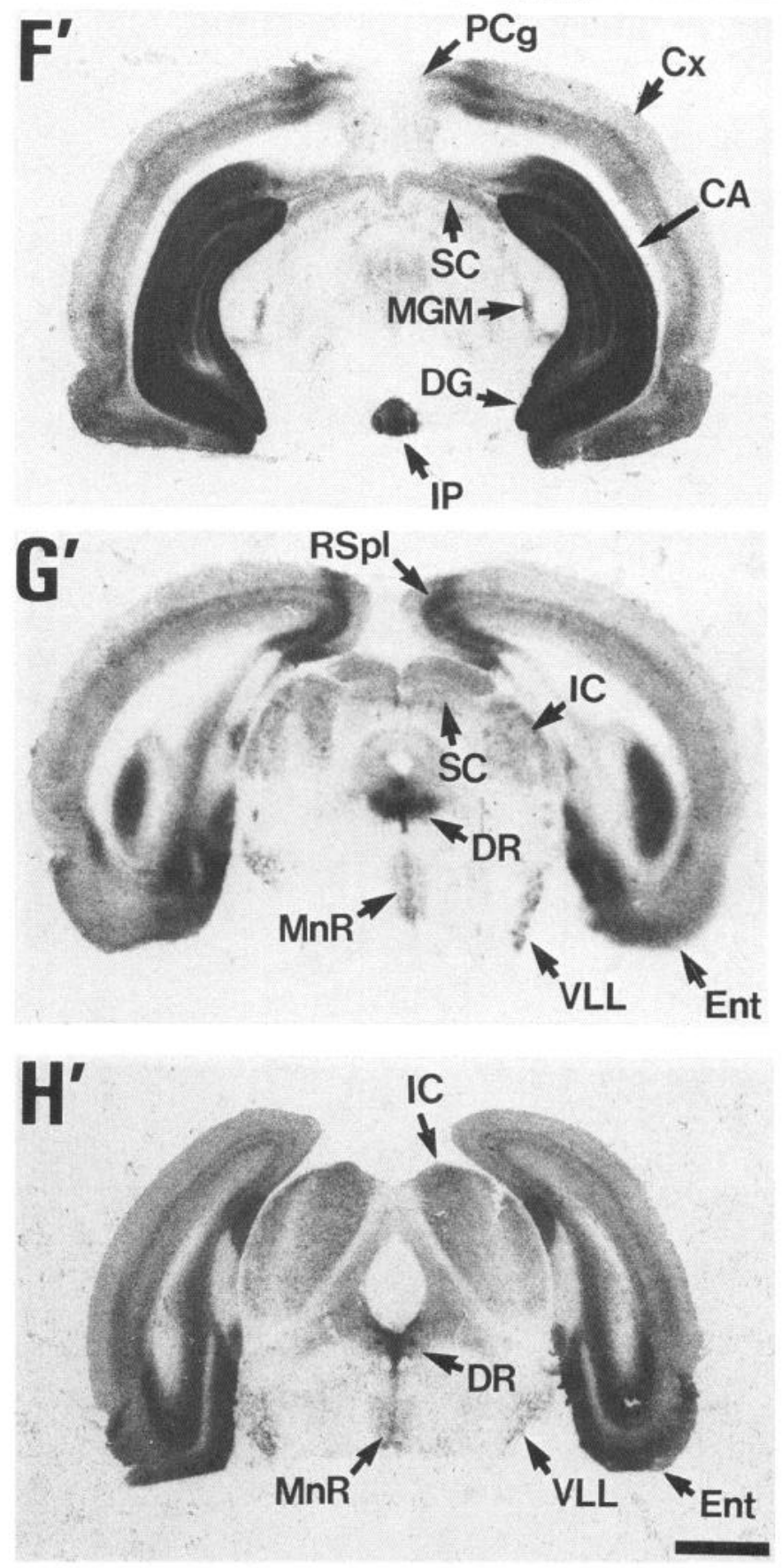
I

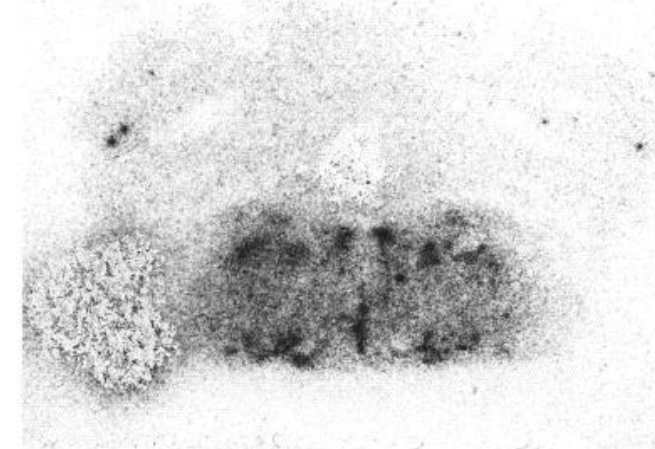

J

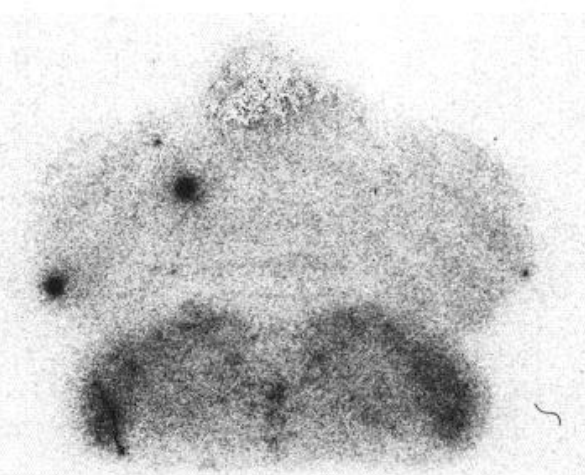

\section{K}

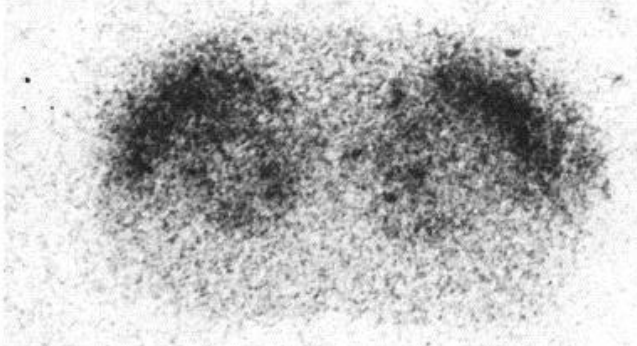

L

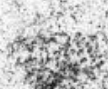

I'
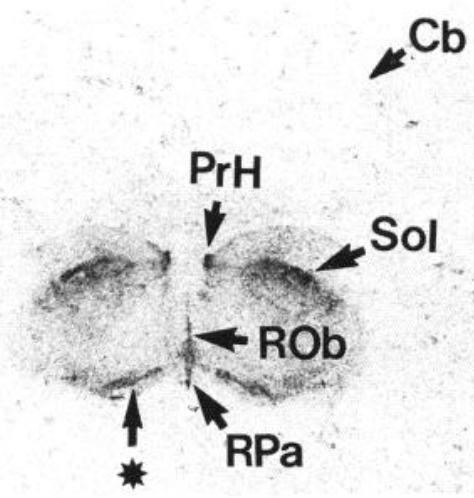

J'
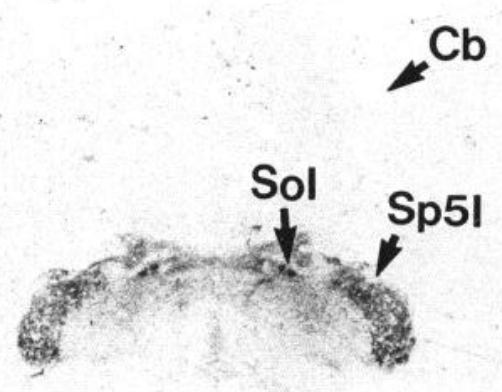

\section{$\mathbf{K}^{\prime}$}



L' 

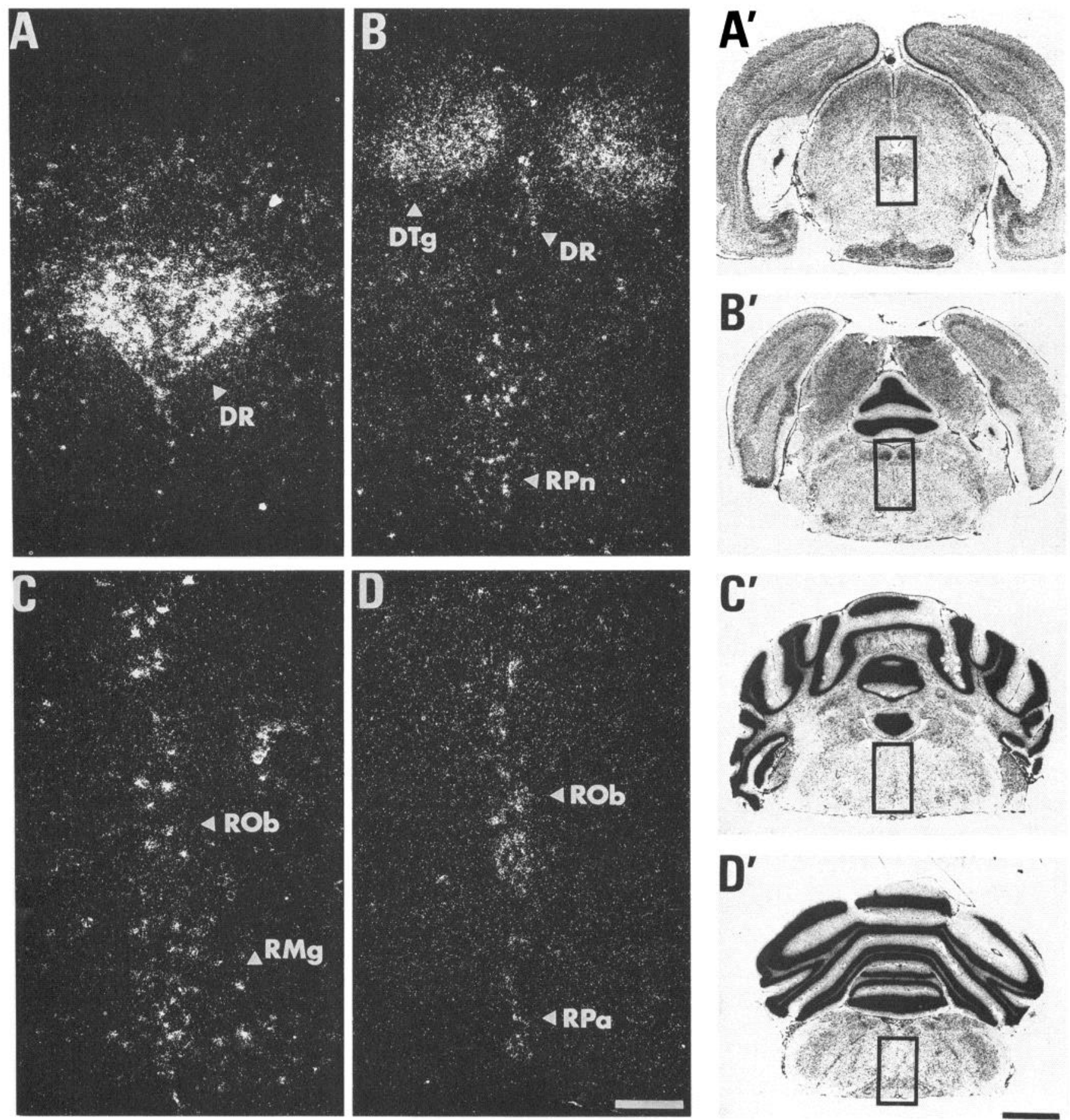

Figure 3. Autoradiographic visualization of 5-HT ${ }_{1 \mathrm{~A}}$ receptor mRNA in the raphe nuclei. $A-D$, The dark-field photomicrographs show the presence of high densities of autoradiographic grains in different raphe nuclei. Autoradiograms were generated by dipping hybridized slides into Kodak NTB-3 emulsion. $A^{\prime}-D^{\prime}$, The same slides as in $A-D$ were stained with cresyl violet. The rectangular frames indicate the regions shown at higher magnification in the dark-field pictures. Scale bars, $2 \mathrm{~mm}$.

mediately dorsal to the medial lemniscus, the region between the raphe magnus nucleus and the lateral part of the pyramidal tracts corresponding to the nucleus reticularis magnocellularis pars alpha and the parapyramidal region (as defined by Sasek and Helke, 1989), the paramedian reticular nucleus, and the area immediately dorsal to the inferior olive (Fig. 2I,I). These regions contain 5-HT neurons of the B9, B3, B2, and B1 groups
(Dahlström and Fuxe, 1964; Steinbush, 1984), respectively. It is tempting to speculate whether also in some of these regions 5 - $\mathrm{HT}_{1 \mathrm{~A}}$ receptors could be located on serotoninergic cells. In line with this hypothesis, 5,7-DHT treatment results in a marked loss of ${ }^{3} \mathrm{H}-8-\mathrm{OH}-\mathrm{DPAT}$ binding also in the parapyramidal region (Thor et al., 1990).

Intermediate levels of hybridization were detected in the an- 



Figure 4. Distribution of 5-HT 1 receptor mRNA and binding sites in the rat septum at two different levels. $A$ and $D$, Dark-field photomicrographs showing the presence of a high density of $5-\mathrm{HT}_{1 \mathrm{~A}}$ receptor mRNA in the medial septal nucleus and the nuclei of the vertical limb of the diagonal band of Broca. Lower densities were seen in nuclei of the lateral septum. $B$ and $E$, Autoradiograms obtained from consecutive sections incubated with ${ }^{3} \mathrm{H}-8-\mathrm{OH}-\mathrm{DPAT}$. In contrast with the mRNA, $5-\mathrm{HT}_{1 \mathrm{~A}}$ sites were very abundant in the lateral septum and only low levels were present in the medial septal nucleus. $C$ and $F$, The same slides as in $A$ and $D$ stained with cresyl violet. The frames indicate the regions shown at higher magnification. Scale bars: $E, 1 \mathrm{~mm}$ for $A, B, D$, and $E$; and $F, 2 \mathrm{~mm}$ for $C$ and $F$.

terior pretectal area; deep mesencephalic nucleus, in particular in a region dorsolateral to the red nucleus; inferior colliculus, especially in the ventral part of its central and external nuclei (Fig. 2G,H); dorsal and ventral parabrachial nuclei; superior vestibular nucleus; and nucleus of the spinal tract of the trigeminus, but only in its interpolar and caudal parts (Fig. 2J,K). Labeled cells were seen in the nucleus of Darkschewitsch; interstitial nucleus of Cajal; parabigeminal nucleus; lateral superior olive; dorsolateral tegmental nucleus; caudal part of the pontine reticular formation; gigantocellular, paragigantocellular and lateral reticular nuclei; nucleus ambiguus, at least at caudal levels; and along the ventral and lateral borders of the hypoglossal nucleus. Hybridization signals of low intensity were still de- tectable in the superficial gray layer of the superior colliculus (Fig. $2 F, G$ ) and cuneate and gracile nuclei, with the exception of the most lateral part of the cuneate nucleus, which presented a small area with a high density of hybridization. We could not detect any specific signal in the locus coeruleus, vestibular nuclei other than the superior and inferior olive, and cerebellum (Fig. $2 I, J)$. The regional distribution and relative density of ${ }^{3} \mathrm{H}-8-$ OH-DPAT binding sites in the brainstem were the same as for the hybridization signal (Fig. $2 F^{\prime}-K^{\prime}$ ).

In the spinal cord, intermediate to low hybridization signals were seen in the dorsal horn (Fig. $2 L$ ), mainly in laminae 3 and 4 , while $5-\mathrm{HT}_{1 \mathrm{~A}}$ receptors were present at high density (Fig. $2 L$ ). The postsynaptic localization of the receptors at this level 

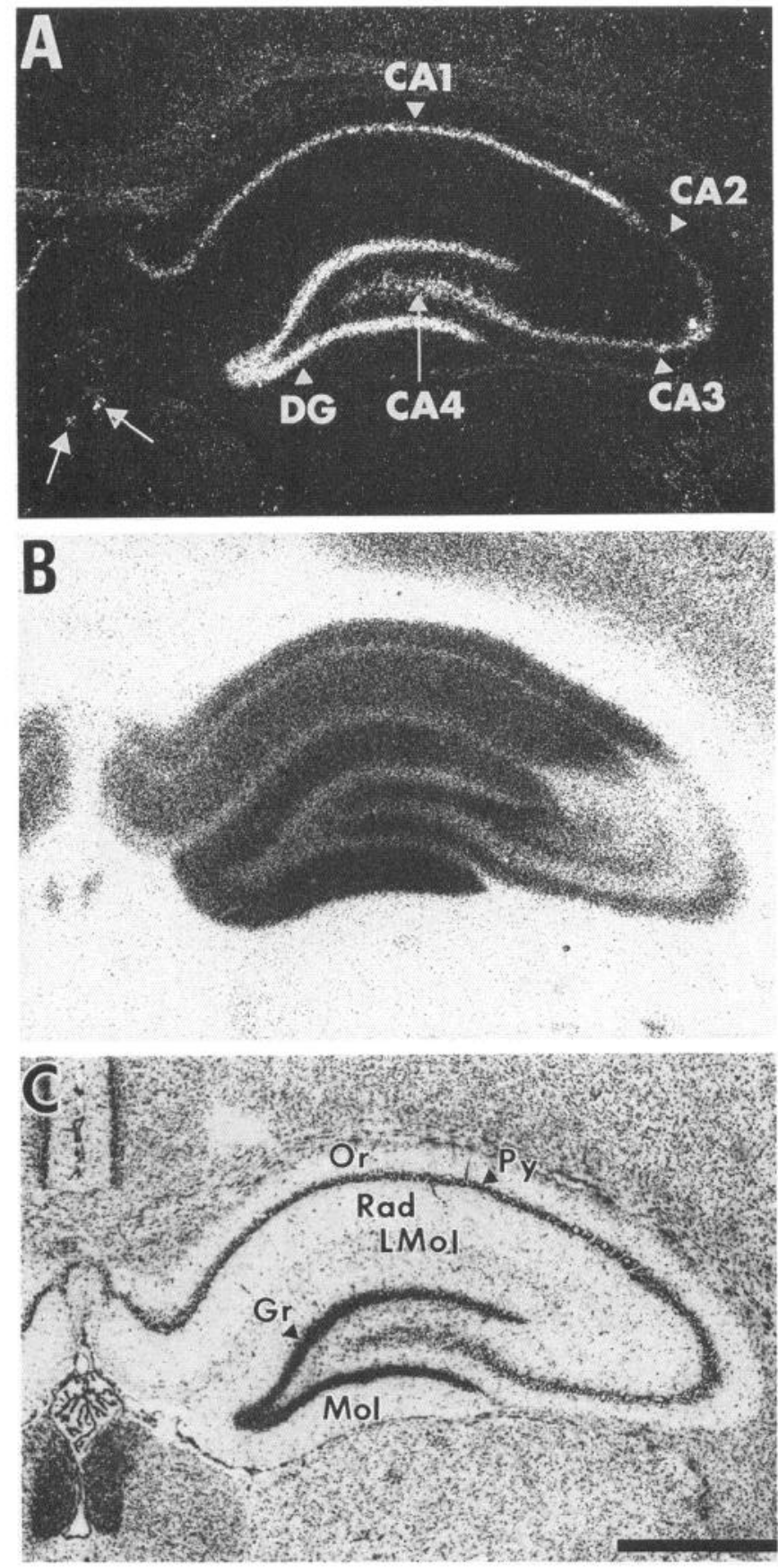

Figure 5. Distribution of 5-HT $\mathrm{HA}_{1 \mathrm{~A}}$ receptor $\mathrm{mRNA}$ and binding sites in the rat hippocampus. $A$, The dark-field photomicrograph shows the high density of 5-HT $\mathrm{HA}_{1 \mathrm{~A}}$ receptor mRNA in the granule cell layer of the dentate gyrus and in the pyramidal cell layer of Ammon's horn. The hybridization level was higher in the CA1 and CA4 than in CA2 and CA3. B, Autoradiogram from a consecutive section incubated with ${ }^{3} \mathrm{H}-$ 8-OH-DPAT show the high density of $5-\mathrm{HT}_{1 \mathrm{~A}}$ receptors present in the molecular layer of the dentate gyrus, higher in the internal than in the had been suggested (Daval et al., 1987), and our data provide direct evidence for an expression of $5-\mathrm{HT}_{1 \mathrm{~A}}$ receptors by neurons intrinsic to the dorsal horn. As recent results from our laboratory (Waeber et al., unpublished observations) have shown that $5-\mathrm{HT}_{1 \mathrm{~A}}$ receptors have been found in the rabbit dorsal root ganglia, they could also represent receptors to be transported to the sensory fibers terminals in the dorsal horn. This would at least in part explain the lack of correlation between mRNA and receptor levels seen in the dorsal horn. Anatomical studies also support this hypothesis (Hoffert et al., 1983; Maxwell et al., 1983).

\section{Conclusion}

The present results demonstrate that $5-\mathrm{HT}_{1 \mathrm{~A}}$ receptors are selectively expressed by different neuronal populations in the rat brain. The specificity of the hybridization signals has been verified on the basis of several criteria that we have also applied to other neurotransmitter receptor mRNAs (see Vilaró et al., 1991a). We compared in situ hybridization histochemistry data with those derived from receptor autoradiography. A good correlation was generally observed between $5-\mathrm{HT}_{1 \mathrm{~A}}$ receptor mRNA and binding sites in both distribution and relative density, as seen, for example, in many thalamic, hypothalamic, and brainstem nuclei. This suggests that $5-\mathrm{HT}_{1 \mathrm{~A}}$ receptors are expressed by cells intrinsic to these regions. A lack of correlation was seen only in the septum and dorsal horn of the spinal cord. Apparently poor correlations were seen in the hippocampus, olfactory bulb, and primary olfactory cortex, but they are easily accounted for by the cellular organization of the area. It appears, therefore, that $5-\mathrm{HT}_{1 \mathrm{~A}}$ receptors are predominantly somatodendritic receptors.

$\begin{array}{ll}\text { Appendix } \\ \text { Abbreviations used in the figures } \\ \text { ACg } \quad \text { anterior cingulate cortex } \\ \text { ACo } & \text { anterior cortical amygdaloid nucleus } \\ \text { CA } & \text { Ammon's horn } \\ \text { CA1 } & \text { field CA1 of Ammon's horn } \\ \text { CA2 } & \text { field CA2 of Ammon's horn } \\ \text { CA3 } & \text { field CA3 of Ammon's horn } \\ \text { CA4 } & \text { field CA4 of Ammon's horn } \\ \text { Cb } & \text { cerebellum } \\ \text { Cl } & \text { claustrum } \\ \text { CM } & \text { centromedial thalamic nucleus } \\ \text { Cx } & \text { neocortex } \\ \text { DG } & \text { dentate gyrus }\end{array}$

external limb. High densities of receptors are also seen in strata oriens and radiatum of CA1 and CA4 field of Ammon's horn. The dentate granule cell layer, Ammon's horn pyramidal cell layer, and stratum lacunosum moleculare presented lower densities of sites. $C$, The same slide stained with cresyl violet. Both $5-\mathrm{HT}_{1 \mathrm{~A}}$ receptor mRNA and binding sites were detected in the medial habenula (arrows in $A$ ). Scale bar, $1 \mathrm{~mm}$.

Figure 6. Distribution of 5-HT ${ }_{1 \mathrm{~A}}$ receptor mRNA in different rat cortical areas. $A-C$, Dark-field photomicrographs from emulsion-dipped tissue $A^{\prime}-C^{\prime}$, The same fields as in $A-C$ are shown with cresyl violet staining. The numbered dots correspond to the layers of the different cortical areas shown. $A^{\prime \prime}-C^{\prime \prime}$. The same slides as in $A-C$ stained with cresyl violet and shown at low magnification. The frames indicate the regions shown in the dark-field pictures above. $A$ is taken from the neocortex, in particular from the frontoparietal somatosensory cortex. Autoradiographic grains are clearly present in the superficial part of layer $5 . B$ shows the primary olfactory cortex. Cells of layers 2 and 3 are labeled. $C$ represents the medial entorhinal cortex, where cells of layer 2 present high densities of autoradiographic grains. A second band containing a lower density of grains is seen in layers 5 and 6 . Scale bars: $C, 0.2 \mathrm{~mm}$ for $A-C$ and $A^{\prime}-C^{\prime} ; C^{\prime \prime}, 2 \mathrm{~mm}$ for $A^{\prime \prime}-C^{\prime \prime}$. 

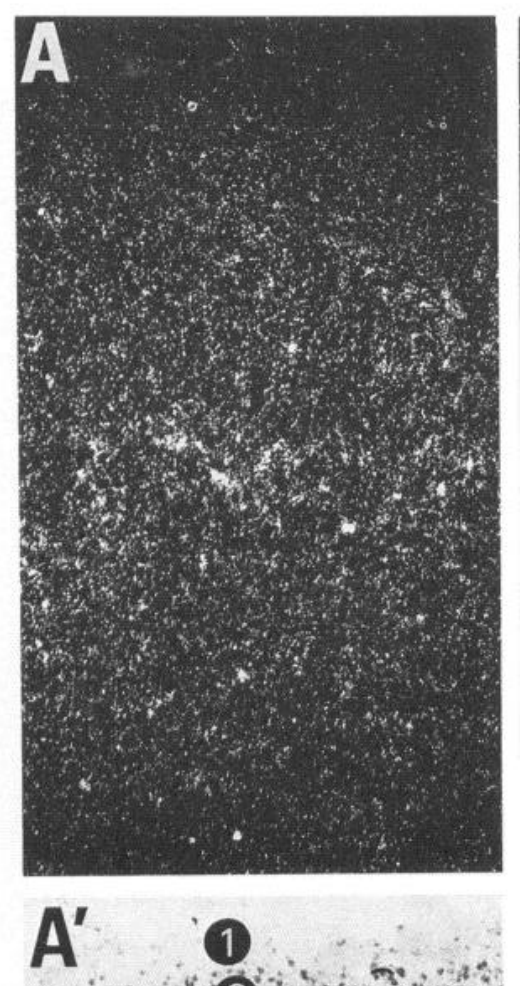
28 (2) 13 3 (x)

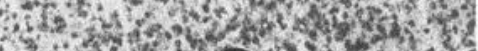

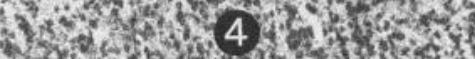

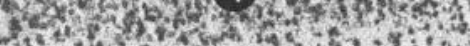

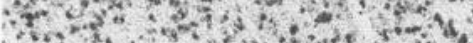

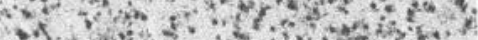
M.

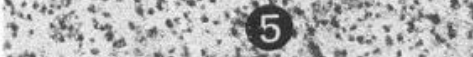

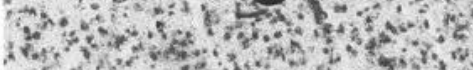

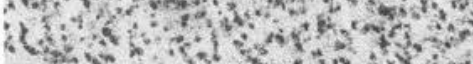
4 -

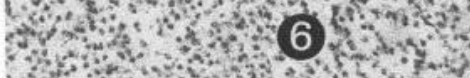

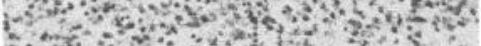

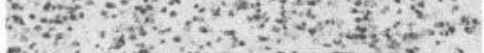

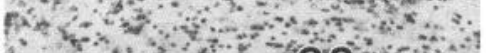

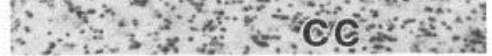

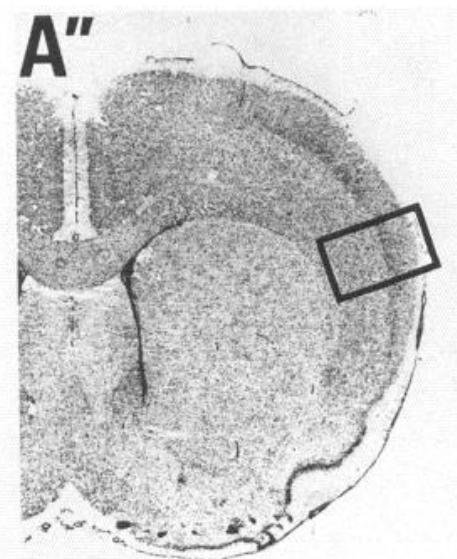

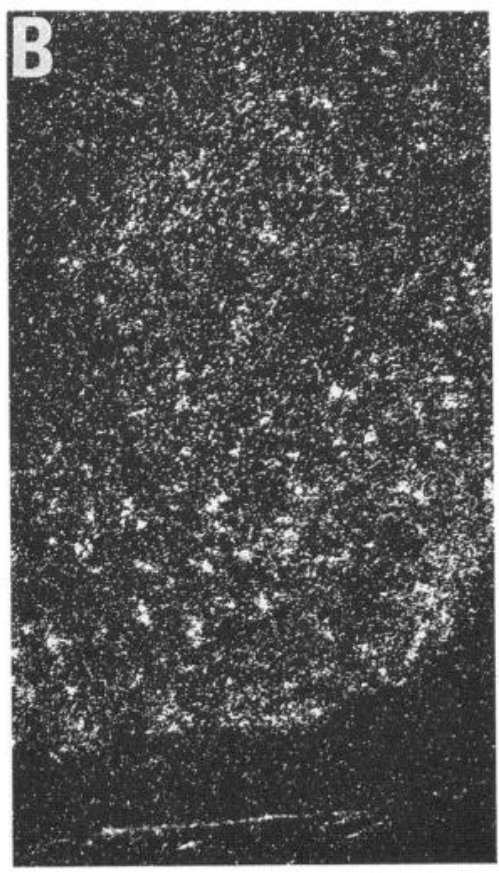



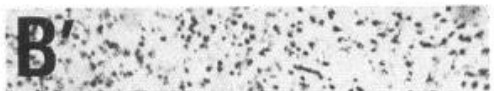
Qne

BC. $6 a^{2}+243$

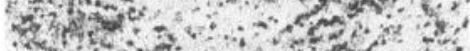
(2) LA



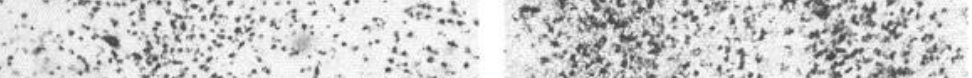

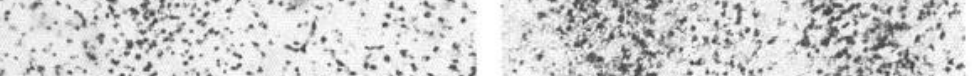



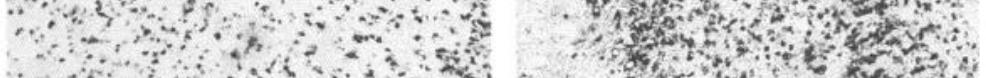

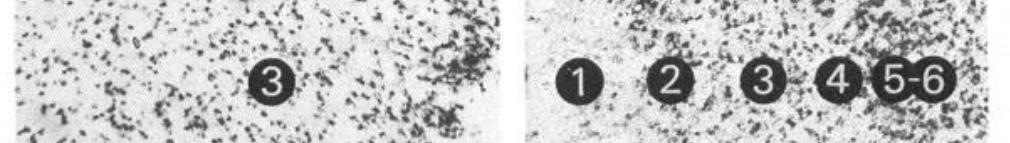








$\begin{array}{ll}\text { Dh } & \text { dorsal horn of the spinal cord } \\ \text { DM } & \text { dorsomedial hypothalamic nucleus } \\ \text { DR } & \text { dorsal raphe } \\ \text { DTg } & \text { dorsal tegmental nucleus of Gudden } \\ \text { En } & \text { endopiriform nucleus } \\ \text { Ent } & \text { entorhinal cortex } \\ \text { Fr } & \text { frontal cortex } \\ \text { Gr } & \text { granule cell layer of the dentate gyrus } \\ \text { IC } & \text { inferior colliculus } \\ \text { IP } & \text { interpeduncular nucleus } \\ \text { LMol } & \text { stratum lacunosum moleculare of Ammon's horn } \\ \text { LOT } & \text { nucleus of the lateral olfactory tract } \\ \text { LSD } & \text { lateral septal nucleus, dorsal part } \\ \text { LSI } & \text { lateral septal nucleus, intermediate part } \\ \text { Me } & \text { medial amygdaloid nucleus } \\ \text { MGM } & \text { medial geniculate nucleus, medial part } \\ \text { MnR } & \text { median raphe nucleus } \\ \text { Mol } & \text { molecular layer of the dentate gyrus } \\ \text { MS } & \text { medial septal nucleus } \\ \text { OB } & \text { olfactory bulb } \\ \text { Or } & \text { stratum oriens of Ammon's horn } \\ \text { PCg } & \text { posterior cingulate cortex } \\ \text { PO } & \text { primary olfactory cortex } \\ \text { PrH } & \text { prepositus hypoglossal nucleus } \\ \text { Py } & \text { pyramidal cell layer of Ammon's horn } \\ \text { Rad } & \text { stratum radiatum of Ammon's horn } \\ \text { RMg } & \text { raphe magnus nucleus } \\ \text { ROb } & \text { raphe obscurus nucleus } \\ \text { RPa } & \text { raphe pallidus nucleus } \\ \text { RPn } & \text { raphe pontis nucleus } \\ \text { RSpl } & \text { retrosplenial cortex } \\ \text { Rt } & \text { reticular thalamic nucleus } \\ \text { SC } & \text { superior colliculus } \\ \text { Sol } & \text { nucleus of the solitary tract } \\ \text { Sp5C } & \text { nucleus of the spinal tract of the trigeminal nerve, caudal } \\ & \text { part } \\ \text { Sp5I } & \text { nucleus of the spinal tract of the trigeminal nerve, inter- } \\ & \text { polar part } \\ \text { TT } & \text { taenia tectae } \\ \text { VDB } & \text { nucleus of the vertical limb of the diagonal band of Broca } \\ \text { VLL } & \text { ventral nucleus of the lateral lemniscus } \\ \text { VMH } & \text { ventromedial hypothalamic nucleus } \\ & \end{array}$

\section{References}

Aghajanian GK, Sprouse JS, Rasmussen K (1988) Electrophysiology of central serotonin receptor subtypes. In: The serotonin receptors (Sanders-Bush E, ed), pp 225-252. Clifton, NJ: Humana.

Albert P, Zhou QY, Van Tol HHM, Bunzow JR, Civelli O (1990) Cloning, functional expression and mRNA tissue distribution of the rat 5-hydroxytryptamine ${ }_{1 \mathrm{~A}}$ receptor gene. J Biol Chem 265:58255832.

Albretsen C, Haukanes B-I, Aasland R, Kleppe K (1988) Optimal conditions for hybridization with oligonucleotides: a study with myconcogene DNA probes. Anal Biochem 170:193-202.

Arvidsson L-E, Hacksell JLG, Nilsson S, Hjorth A, Carlsson P, Lindberg D, Sanchez D, Wikström H (1981) 8-Hydroxy-2-(di-n-propylamino)tetralin, a new centrally acting 5-hydroxytriptamine receptor agonist. J Med Chem 24:921-923.

Bayer SA (1985) Hippocampal region. In: The rat nervous system, Vol 1, Forebrain and midbrain (Paxinos G, ed), pp 335-352. Marrickville, Australia: Academic.

Branchek T, Zgombick J, Macchi M, Hartig P, Weinshank R (1991) Cloning and expression of a human 5-HT $\mathrm{H}_{1 \mathrm{D}}$ receptor. In: Serotonin: molecular biology, receptors and functional effects (Fozard JR, Saxena PR, eds), pp 21-32. Basel: Birkhäuser.

Colino A, Halliwell JV (1987) Differential modulation of three separate $\mathrm{K}^{+}$-conductances in hippocampal CA1 neurons by serotonin. Nature 328:73-77.

Dahlström A, Fuxe K (1964) Evidence for the existence of monoamine-containing neurons in the central nervous system. Acta Physiol Scand 62[Suppl 232]:1-55.

Daval G, Vergé D, Basbaum AI, Bourgoin S, Hamon M (1987) Au-

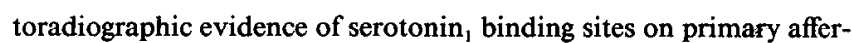
ent fibers in the dorsal horn of the rat spinal cord. Neurosci Lett 83: 71-76.

Dohlman HG, Caron MG, Lefkowitz RJ (1987) A family of receptors coupled to guanine nucleotide regulatory proteins. Biochemistry 26 : 2657-2664.

El Mestikawy S, Riad M, Laporte A-M, Vergé D, Daval G, Gozlan H, Hamon M (1990) Production of specific anti-rat 5- $\mathrm{HT}_{1 \mathrm{~A}}$ receptor antibodies in rabbits injected with a synthetic peptide. Neurosci Lett 118:189-192.

Gozlan H, El Mestikawy L, Pichat L, Glowinski J, Hamon M (1983) Identification of presynaptic serotonin autoreceptors using a new ligand: ${ }^{3} \mathrm{H}-\mathrm{PAT}$. Nature 305:140-142.

Hall MD, El Mestikawy S, Emerit MB, Pichat L, Hamon M, Gozlan H (1985) [ $\left.{ }^{3} \mathrm{H}\right] 8$-hydroxy-2-(di- $n$-propylamino)tetralin binding to preand postsynaptic 5-hydroxytryptamine sites in various regions of the rat brain. J Neurochem 44:1685-1696.

Hartig PR (1989) Molecular biology of 5-HT receptors. Trends Pharmacol Sci 10:64-69.

Hjorth S, Carlsson A, Lindberg P, Sanchez D, Wikström H, Arvidsson L-E, Hacksell U, Nilsson JLG (1982) 8-Hydroxy-2-(di-n-propylamino)tetralin, 8-OH-DPAT, a potent and selective simplified ergot congener with central 5-HT-receptor stimulating activity. J Neural Transm 55:169-188.

Hoffert MJ, Miletic V, Ruda MA, Dubner R (1983) Immunocytochemical identification of serotonin axonal contacts on characterized neurons in laminae I and II of the cat dorsal horn. Brain Res 267: 361-364.

Leranth C, Frotscher M (1989) Organization of the septal region in the rat brain: cholinergic-GABAergic interconnections and the termination of hippocampo-septal fibers. J Comp Neurol 289:304-314.

Marcinkiewicz M, Vergé D, Gozlan H, Pichat L, Hamon M (1984) Autoradiographic evidence for the heterogeneity of 5-HT sites in the rat brain. Brain Res 291:159-163.

Maxwell DJ, Leranth C, Verhofstad AAJ (1983) Fine structure of serotonin-containing axons in the marginal zone of the rat spinal cord. Brain Res 266:253-259.

Mengod G, Martinez-Mir MI, Vilaró MT, Palacios JM (1989) Localization of the $m R N A$ for the dopamine $D_{2}$ receptor in the rat brain by in situ hybridization histochemistry. Proc Natl Acad Sci USA 86: 8560-8564.

Palacios JM, Dietl MM (1988) Autoradiographic studies of serotonin receptors. In: The serotonin receptors (Sanders-Bush E, ed), pp 89137. Clifton, NJ: Humana.

Palacios JM, Waeber C, Hoyer D, Mengod G (1990) Distribution of serotonin receptors. Ann NY Acad Sci 600:36-52.

Pazos A, Palacios JM (1985) Quantitative autoradiographic mapping of serotonin receptors in the rat brain. I. Serotonin-1 receptors. Brain Res 346:205-230.

Peroutka SJ (1990) 5-Hydroxytryptamine receptor subtypes. Pharmacol Toxicol 67:373-383.

Pierce PA, Peroutka SJ (1990) $d$-Lysergic acid diethylamide differentially affects the dual actions of 5-hydroxytryptamine on cortical neurons. Neuropharmacology 29:705-712.

Quirion R, Richard J (1987) Differential effects of selective lesions of cholinergic and dopaminergic neurons on serotonin-type 1 receptors in rat brain. Synapse 1:124-130.

Sasek CA, Helke CJ (1989) Enkephalin-immunoreactive neuronal projections from the medulla oblongata to the intermediolateral cell column: relationship to substance P-immunoreactive neurons. J Comp Neurol 287:484-494.

Steinbush HWM (1984) Serotonin-immunoreactive neurons and their projections in the CNS. In: Handbook of chemical neuroanatomy, Vol 3, Classical transmitter and transmitter receptors in the CNS, Pt II (Björklund A, Hökfelt T, Kuhar MJ, eds), pp 68-125. Amsterdam: Elsevier.

Switzer RC, De Olmos J, Heimer L (1985) Olfactory system. In: The rat nervous system, Vol 1, Forebrain and midbrain (Paxinos G, ed), pp 1-36. Marrickville, Australia: Academic.

Thor KB, Blitz-Siebert A, Helke CJ (1990) Discrete localization of high-density-5-HT ${ }_{1 A}$ binding sites in the midline raphe and parapyramidal region of the ventral medulla oblongata of the rat. Neurosci Lett 108:249-254.

Vergé D, Daval G, Marcinkiewicz M, Patey A, El Mestikawy S, Gozlan H, Hamon M (1986) Quantitative autoradiography of multiple 5-HT, 
receptor subtypes in the brain of control or 5,7-dihydroxytryptaminetreated rats. J Neurosci 6:3474-3482.

Vilaró MT, Martinez-Mir MI, Sarasa M, Pompeiano M, Palacios JM, Mengod G (1991a) Molecular neuroanatomy of neurotransmitter receptor: the use of in situ hybridization histochemistry for the study of their anatomical and cellular localization. In: Current aspects of the neurosciences, Vol 3 (Osborne NN, ed), pp 1-36. London: Macmillan.

Vilaró MT, Wiederhold K-H, Palacios JM, Mengod G (1991b) Muscarinic cholinergic receptors in the rat caudate-putamen and olfactory tubercle belong predominantly to the $\mathrm{m} 4$ class: in situ hybridization and receptor autoradiography evidence. Neuroscience 40:159-167.

Wang RY, Aghajanian GK (1977) Antidromically identified serotoningeric neurons in the rat midbrain raphe: evidence for collateral inhibition. Brain Res 132:186-193.

Weissman-Nanopoulos D, Mach E, Magre J, Demassey Y, Pujol JF (1985) Evidence for the localization of 5- $\mathrm{HT}_{1 \mathrm{~A}}$ binding sites on serotonin containing neurons in the raphe dorsalis and raphe centralis nuclei of the rat brain. Neurochem Int 7:1061-1072. 